\title{
The Effectiveness of using Learning Diaries in developing Critical Writing Skills for Al Azhar Preparatory School pupils
}

Asmaa abdel Fattah Eid Mostafa

M.A Candidate, October 6 University

\section{Abstract}

he aim of this study was to investigate the
effect of learning diaries on developing
Critical writing skills for Al Azhar preparatory school pupils. An quasi experimental method was adopted. Sample members of the study were 80 students, $(N=80)$. They were randomly chosen and divided into two groups: the experimental group and the control group after being sure that they were equivalent. A critical writing test was used to measure the critical writing skills for the Al Azhar preparatory school pupils of the sample members. Based on the students' mean scores of the test, results showed that the performance level of EDSs' writing was low. The experimental group students were trained in critical writing skills through the use of diaries learning, while the regular instruction was used with the control group. To achieve the aims of the study, the researcher designed a critical writing skills pre/ post test to measure the students' critical writing skills. It was administered to them before and after the experiment. The mean scores of the pre / post administrations of the test were treated statistically. Results also showed that there is a statistically significant difference between the post-test administrations mean scores of the experimental and the control groups in critical writing skills in favor of the experimental group."

Key words: Learning Diaries, Critical Writing

\section{Introduction}

English has become the major window for us to explore and get in touch with the outside world. Clearly, a good command of English is the key to social and economic advancements. What adds to the importance of English language learning is the extraordinary spread 
of English language throughout the world lately which has brought about its significant part in the academic, cultural, and scene of a growing number of countries. The mandates to teach English in earlier grades, consolidated with a growing exposure to the English language through television, newspapers, prevalent culture, tourism, travel, and the internet, have further expanded the importance of the language. In numerous countries, English has become the second language of academia, requiring learners to be proficient enough to have the capacity to read a large amount of text based material in English or even to partake in discussions or make oral presentations in English at international conferences (MCDougald,2009). So, if we want to keep in touch with scientific progress, we must be interested in teaching English, and learning its four skills: listening, speaking, reading, and writing (Hasman,2000).

Although critical thinking is almost a new concept in language education, it is considered as one of the main concerns of researchers in language acquisition. Researchers (e.g. Gelder, 2005; Willingham, 2007; Akyuz \& Samsa, 2009) believe that critical thinking is one of the main goals of education, so it should receive more attention and all of its possible effects on language learning should be investigated. They indicate that learners who think more critically are more successful in language learning; furthermore, some others (Singhal, 2001; Shang, 2011; Mokhtari \& Sheorey, 2002) believe that successful writers use more effective and a wider range of strategies rather than unsuccessful writers.

Critical ability is presently regarded as the fourth literacy in addition to the conventional " $3 \mathrm{R}$ " literacies 
(reading, writing, and arithmetic) (Bean et al., 2002 ;Poulson \& Wallace, 2004). Having critical ability is highly valued in an academic context. It is considered one of the objectives of higher education .

As human societies emerged, the development of writing was driven by pragmatic exigencies such as exchanging information, maintaining financial accounts, codifying laws and recording history. Around the 4th millennium $\mathrm{BC}$, the complexity of trade and administration in Mesopotamia outgrew human memory, and writing became a more dependable method of recording and presenting transactions in a permanent form (Hamp \& Heasly, 2006).

Critical writing is the process of drawing together other aspects of critical thinking in order to present a robust case to the reader. Higher-level critical writing examines the evidence in depth, identifying main themes and sub-themes in a way that is clear and logical for the reader to understand. You will be assessed on clarity, accuracy, relevance, depth, breadth, logic, significance and fairness of the evidence selected, so signposting the reader between the themes is essential (Kirkgoz, 2009).

Critical Writing is a complex skill to learn and to teach, as it necessitates the acquisition of many other skills (Ningrum et al., 2013). According to Meyers (2005) writing is similar to producing speech .It is a way of communicating with others through paper. As a writer writes, he performs an action of producing, organizing and expressing ideas in a way that is comprehensible for the reader or the audience .

One way of improving Critical writing skills is through constant writing. The more students write the 
more their writing skills develop. But writing has to be meaningful to the writer, and even more important, writing has to be interesting. Thus, the notion of 'diary' came into existence as a reaction against the traditional methods of writing where the focus is usually on the end product stressing correctness of form and paying attention to the mechanics of writing rather than the message the writer tries to send (CamTESOL Conference, 2008).

Diaries, according to the literature, are part of the learner-centered approach where learners take responsibility of their own and where learning is more successful. McDonough and McDonough emphasize the role of diaries as a means for autonomous learning where the writer is in control of his/her own writing not worrying about grammar and the mechanics of writings. Allison further adds that when learners choose their own topic to write about, they are more immersed in the language. The more learners have choices to make, the better learning takes place and the more learners are motivated and interested in the activity. (Bagheri, \& Pourgharib, 2013)

A learning diary is a tool of reflection. It helps the student to assess what she/he has learned on a lesson, and therefore also the teacher. The aim of a learning diary is to analyze and comment on the lesson. As such, it can be used to replace or supplement an essay or a final exam. The key to writing a learning diary is to draw on the lesson s, but instead of just repeating what the teacher has said, the students should speak with their own voice. A diary is a subjective view, and a learning diary should reflect what the student has heard and learnt; it's the student's own analysis and 
insights that count. The teacher's ideas may even be taken further and elaborated on (Barjesteh, Vaseghi, \& Gholami, 2011)..

According to (Zittoun, Gillespie, 2011). In the learning diary pupils can, for example

- Discuss how did the classes and materials relate to your prior learning and life experience

- Compare and contrast with the previous knowledge you have

- criticize or defend a point

- Review what was new or interesting

- Discuss how you could utilize the things discussed in your own work

- give feedback or (constructive) criticism to the teacher

The following study investigates the usefulness of diary writing in a writing class. Diary writing as a meaningful and most probably interesting process of writing, allows students to write freely and continuously. The teacher's role in this process is supervision and encouragement only standing far from judgment and correcting

\section{Context of the Problem:}

The problem of the study could be stated in weakness in the required English Critical writing of $\mathrm{Al}$ Azhar preparatory school pupils . So the present study attempts to develop these skills via the use of the learning diaries .

\section{Study pilot:}

The researcher of the present study made sure of the problem through three ways:

First: conducting a pilot study trying to identify the reality of teaching EL in general, and teaching critical 
writing in first year prep stage in particular. The pilot study included:

1. Interviewing questions: With $10 \mathrm{EL}$ teachers; the questions of the interview included if critical writing is developed or not, the teaching methods used in developing critical writing and its assessment tools, what are difficulties in teaching critical writing. The researcher found: Most EFL teachers assured that pupils cannot achieve high scores in midterm and final exam. This clearly represents in the weakness of students standards in comprehend critical writing skills. Teachers also commented that students tend to write separating sentences without any thinking or analysis in deep meaning. They cannot organize their ideas.

2. Interviewing with some students in Al Azhar preparatory school pupils who assured the difficulty of understanding and developing critical writing skills and dealing with along comprehension writing text.

Second : Reviewing literature and previous studies related to developing critical writing in foreign language classroom such as Ateș, (2013) , Özensoy, (2011). Kurland (2010), Brody, (2008) , Macknish (2011) , Knott, (2012) , Bagcı\& Sahbaz, (2012)

Finally : Administering a writing test on 30 second for Al Azhar preparatory school pupils. The test measures some skills of critical writing. The result was that 70 got less than the average score. The students write separating sentences can't follow the natural rules of writing. They also found difficultly in writing multiples 
syllables words. They did not use critical thinking in writing sentences.

\section{Questions of the Study:}

The present study attempted to answer the following main question :

What is the effect of using the learning diaries on developing $\mathrm{Al}$ Azhar Preparatory school Pupils required EFL critical writing skills?

Two questions were derived from the main question :

1. What are the required EFL critical writing skills for Al Azhar preparatory school pupils ?

2. What is the effect size of the learning diaries on developing Al Azhar preparatory school pupils ' required critical writing skills in EFL?

\section{Aims of the Study :}

The present study aimed at :

1. Identifying EFL critical writing skills required for Al Azhar preparatory school pupils.

2. Identifying the effect of diaries learning on developing Al Azhar preparatory school pupils ' required EFL critical writing skills.

\section{Hypotheses of the Study :}

1. There is a statistically significant difference between the mean scores of the experimental and the control groups on the post- administration of the critical writing skills test, in favor of the experimental group . 
2. There is a statistically significant difference between the mean scores of the experimental group on the pre - and post administrations of the critical writing test in favor of the post administration of the critical writing test.

\section{Delimitations of the Study:}

This study was confined to:

1. Sample delimitations two groups of 80 students were randomly assigned to the control and experimental groups 40 pupils each. Therefore the results of the present study can be generalized only within that population .

2. Place delimitations: in Al Azhar preparatory school where the researcher was familiar with several teachers in the school.

3. Time delimitations: applying the study in the second term of the school year 2019-2020.

4. Subject delimitations: measuring the effect of the learning diaries on developing critical writing skills for Al Azhar preparatory school pupils. Develop only the (5) required critical writing skills for Al Azhar preparatory school pupils.

\section{Variables of the Study:}

- The independent variable: Learning Diaries.

- The dependent variable: Developing Critical Writing Skills.

\section{Significance of the Study:}

The present study is expected to help in the following areas : 
1. Encouraging students to be more positive and active in the learning process.

2. Encouraging teachers to assign out of class activities as well as in class.

3. Providing activities to help students read more often using critical writing skills.

4. Encouraging teachers to model critical writing and critical skills with students.

5. Helping teachers follow the learning diaries for developing pupils' EFL critical writing skills in preparatory stage .

6. Paving the way for other researchers to conduct further studies on developing pupils' critical writing skills using diaries learning in the other educational stages and in other EFL critical writing skills in preparatory stage.

7. Helping students achieve their critical writing skills through using diaries learning.

\section{Review of literature}

Writing is a procedure that needs not only ideas but vocabulary, grammar and punctuation to express those ideas. Harmer (2004) believes that good writing is a complex process compared to speech. To master writing, a writer needs to master all the features related to it including a rich vocabulary, knowledge of grammar and the mechanics of writing. (Bitchener, 2008).

Although, teacher-written feedback in seen by both teachers and students as necessary in the writing process (Goldstein, 2004\& Ferris, 2002), some 
authors believe that it has a detrimental effect on students' writing (Truscott, 2007; Truscott \& Hsu, 2008). For example, Truscott (2004) argues that corrective feedback may have a negative effect on students' writing fluency which might affect their overall writing. Hence, teachers need to provide indirect feedback (Ferris, 2004).

The most characteristic features of critical writing are:

1. Clear and confident refusal to accept the conclusions of other writers without evaluating the arguments and evidence that they provide;

2. Balanced presentation of reasons why the conclusions of other writers may be accepted or may need to be treated with caution;

3. Clear presentation of your own evidence and argument, leading to your conclusion; and

4. Recognition of the limitations in your own evidence, argument, and conclusion.

Goldstein, (2004) notes that students prefer feedback on their overall writing such as topic, organization coherence and cohesion as well as on vocabulary, spelling, grammar and punctuation. As a reaction towards the traditional methods of writing, the idea of 'diary' came into existence. The word 'diary' came from the Latin word 'diarium' where 'di-' means 'day' in modern English and the suffix 'arium' and its modern equivalent the suffix 'ary' stands for 'in connection with or pertaining to'. Thus, a diary is a daily log that records the events that happen during the 
day. It is updated on a daily basis, private and written for an audience of one.

An extensive review of the literature has revealed multiple definitions for a diary (Hiemstra, 2001; Johnson, 2002; Curtis \& Bailey, 2009; Barjesteh et al. 2011; Zittoun \& Gillespie, 2011). For instance, most authors see that a diary is usually handwritten, arranged by date for the expression of personal feelings, thoughts and experiences on daily basis and it is not intended for publication (Johnson, 2002; Curtis \&Bailey, 2009). Others look at diaries as a kind of freewriting activity where writers write without fear of being evaluated (Barjesteh et al., 2011). Still, others see it as an introspective research tool for the initiation of writing and communicating meaning. Bailey (2009), for example, defines a diary study as a first person account of a language learning or teaching experience written regularly and is analyzed later for recurring themes. Similarly, Hiemstra (2001) writes about learning diaries where learners record their thoughts, feelings and reactions to specific course activities.

Learning diary is a tool for evaluating and implementing personal learning. The purpose is to keep record and reflect on what has been learned through the class. You are expected to relate lectures to your own prior experiences, related readings, and knowledge. Analyze critically the topics presented during the lectures, report your own insights, observations and reactions towards the lectured material. New knowledge can be linked to your earlier knowledge and experiences. You are also welcome to 
report what remained unclear and obscure. The diary gives also feedback to the lecturer on your learning processes (Walter, 2008).

Learning diary is a task, where you write an entry regarding a particular subject that you learned about on a specific lecture. What makes learning diary more than just a note you take in the class while listening the lecture, is the reflection the student provides as the basis of his or her point of view.The objectives of the learning diary may vary. Besides the content from the lecture and the personal perspective that is put into the learning diary, external sources, for example materials that the student independently found on their own are allowed to be included. These display the understanding and the extent of how much the student has widened his or her scope of knowledge beyond that learned on the lecture (Schunk, \& Zimmerman, 2012).

Likewise, diaries gain more importance in the literature not only for their different uses but mainly for the benefits and gains they may fulfill. A large part of the literature was devoted to a description of this issue. While Barjesteh et al. (2011) talks about a diary being beneficial as it makes students write more, Elbow (1998) stressed the fact that diaries should not be edited which results in increasing students' fluency. They can also use the diaries for reflection to go back and evaluate their own performance. This promotes autonomous learning where students take the responsibility of their own learning, monitor their progress and the strategies they use which will eventually result in developing their cognitive skills (Lagan, 2000; Marefat, 2002 !Hamp \& Heasley, 2006; Kirkgoz, 2009) . Learners can also get their problems solved by talking about them and teachers gain 
valuable insights to the language learning processes. (Peterson, 2012) .It follows that writing is an important skill especially for college students who are going through an important time in their lives where they experience change in their personality and educational career. Thus, it is crucial to find out how classroom practices affect students during their college life. One of the classroom practices that is thought to have an effect on students' progress is "praise', defined as favorable interpersonal feedback (Baumeister et al. 1990) or "positive evaluations made by a person of another's products, performances or attributes ."

Educators, teachers and policy makers agree that students need praise and encouragement no matter at what level they are as it boosts their academic success (Bluestein, 2004; Lipnevich \& Smith, 2008; Schunk \& Zimmerman, 2012). Since writing is an act of confidence, Kirkgoz, (2009:85) "it is not surprising that the scholarly tradition emphasizes responding with encouragement". A senior research associate for the Educational Testing Service (Diedrich claims that praising students' writing will improve their writing practice mere correction of errors. He further adds, praise will work more for the less able students to motivate them to write (Daiker, 2011).

\section{Methods and Procedures:}

\section{Procedures of the study :}

In order to accomplish the aims of the present study, the researchers of the study went through the following procedures :

1. Reviewing the related previous studies in the field of critical writing skills and Diaries Learning . 
2. Designing a checklist for the EFL critical writing skills required for Al Azhar preparatory school pupils.

3. Submitting the checklist to specialized jury members to ensure its validity and so to identify the EFL critical writing skills, required for Al Azhar preparatory school pupils.

4. Preparing an EFL critical writing pre-post test for Al Azhar preparatory school pupils.

5. Submitting the test to specialized jury members and ensuring its validity before using it .

6. Ensuring the reliability of the test before using it .

7. Choosing a random sample of 80 first year of English department students. and dividing it into two groups: a control group and an experimental group (40) students each.

8. Pre-administering the critical writing test to both groups .

9. Using the Diaries Learning with the experimental group and the regular instruction with the control group in teaching EFL critical writing skills .

10. Post-administering the critical writing test to both groups .

11. Collecting and analyzing the obtained data .

12. Presenting and discussing the results of the study .

13. Introducing recommendations and suggestions for further research.

\section{Sample:}

The target population of the present study is $\mathrm{Al}$ Azhar preparatory school pupils . 60 students $(\mathrm{N}=60)$ were randomly selected to involve in the present study. 
All the students were native speakers of Arabic. As for demographics, all the sample members were in the $\mathrm{Al}$ Azhar preparatory school pupils and their average age was 13. The researcher administered the critical writing test at the second semester of the academic school year of the respondents on February , 2019.

\section{Research Design}

The present study is an quasi-experimental study. Two groups were assigned as the participants of the study; the experimental group, and the control group. The research includes two variables; the first variable is a suggested strategy (Learning Diaries.). The second is critical writing. The experimental group was taught via the suggested strategy, while the control group was taught via the regular instruction. The experiment lasted for 8 weeks.

\section{The critical writing Skills Checklist :}

1. The checklist aimed at identifying the required EFL critical writing skills required for Al Azhar preparatory school pupils.

2. Validity of this checklist was used to determine the needed English critical writing skills required for Al Azhar preparatory school pupils to be developed. It includes 5 skills. The checklist was submitted to a panel of jury whom indicated that the checklist was valid.

\section{Content of the checklist :}

Having reviewed the related literature on developing pupils' critical writing skills, the researchers designed a critical writing skills' checklist 
and submitted it to specialized jury members in the English Language Teaching (ELT) so as to determine the degree of importance of each skill (very important, important, less important ) on the checklist.

The jury members stated that the skills in the checklist would be generally adequate and appropriate to its purpose, after deleting skills which had been considered above the Al Azhar preparatory school pupils ' level. So, the checklist became valid, after it had been modified according to the jury members' suggestions to contain (5) skills only, as shown in Appendix I. Thus, the first sub-question of the study about the required EFL critical writing skills for the Al Azhar preparatory school pupils. Students was answered.

The Checklist in its Final Form

\section{Critical Writing Skills}

Uses paragraphs to develop and expand ideas

Give a clear and precise account of the relevant evidence and arguments

Give reasons for conclusion

Recognizes limitations (tends, suggests)

Avoid simplistic conclusions

\section{Instrument of the Study}

The instrument of the study i.e. the preposttest of the required EFL critical writing skills, for Al Azhar preparatory school pupils, was developed by the researchers .

\section{The Pre- Post Critical Writing Test :}

To ensure the validity of the test, the researchers submitted it, in its initial form, to a number of specialized jury members . 
The test became valid when it was modified according to the jury members 'comments and suggestions. One question was changed to suit the level of students as suggested by the jury members. The final form of the test is shown in Appendix II.

To establish the reliability of the test, it was administered to a sample of (35) Al Azhar preparatory school pupils other than the sample of the experiment of the study. Then, the same test was administered to the same group under nearly similar conditions after two weeks .

The reliability coefficient of the test was estimated using Cronbach Alpha Formula. The estimated value $(0.86)$ was considered reliable for the purpose of the present study .

Duration of the critical writing test was estimated by calculating the time spent by calculating the time taken by all the students (30) used for piloting the test, divided by the number of the same students. Thus, the time allotted for the test was counted as shown in the following formula :

Duration of the test $=$ summation of the time taken by all students / the number of the students

Duration of the test $=2210 / 35=70$ minutes

Thus, the time allotted for the test was (70) minutes.

\section{Test Construction}

The test was constructed in the light of the following resources: 
1. Related studies to testing critical writing.

2. English text book for Al Azhar preparatory school pupils.

\section{Test Description}

The critical writing test was constructed and administered by the researcher. To achieve the main aim of designing the test of critical writing, it was important to:

1. Precisely identify the critical writing language skills that should be assessed, and that are assumed to be mastered by Al Azhar preparatory school pupils, and also by reviewing the literature related to writing components that are necessary for Al Azhar preparatory school pupils to acquire.

2. Define the cognitive complexity levels upon which the test items should be constructed, and

3. Determine the appropriate relative weight of the test items to reflect the importance degree of each tested outcome.

The items were constructed according to multiple sources, including course books, previous researches, studies, and similar exams.

The writing section of the test consisted of 10 items. The first passage is titled as "The History of Cars" and the second one is "Nature and Unnature Disasters".

The critical writing items were separated to make it easy for understanding and measuring their components. The critical writing items are as follows:

1. Uses paragraphs to develop and expand ideas 
2. Give a clear and precise account of the relevant evidence and arguments

3. Give reasons for conclusion

4. Recognizes limitations (tends, suggests)

5. Avoid simplistic conclusions

\section{Instructions of the Test (for students)}

The content of the critical writing task was explained clearly for the students through instructions. Moreover, the researcher made sure that the students understood what was required in each activity.

\section{Scoring the Test}

In order to easily and objectively score the test, the researcher developed a model answer for all the items included in the critical writing test and that was after consulting the jury members concerning the distribution of marks for the critical writing sections. All marks for each item were put in (Table 1).

TABLE (1) Scoring the critical Reading Test

\begin{tabular}{|l|c|c|c|}
\hline Question No & Critical Reading Component & Cod & Mark \\
\hline Q1 Passage A\&B & $\begin{array}{c}\text { Uses paragraphs to develop and } \\
\text { expand ideas }\end{array}$ & Ide & 6 \\
\hline Q2 Passage A\&B & $\begin{array}{c}\text { Give a clear and precise account } \\
\text { of the relevant evidence and } \\
\text { arguments }\end{array}$ & Rea & 6 \\
\hline Q3 Passage A\&B & Give reasons for conclusion & Pre & 6 \\
\hline Q4 Passage A\&B & $\begin{array}{c}\text { Recognizes limitations (tends, } \\
\text { suggests( }\end{array}$ & Inf & 6 \\
\hline Q5 Passage A\&B & Avoid simplistic conclusions & Exc & 6 \\
\hline Total Mark & \multicolumn{2}{|l}{} \\
\hline
\end{tabular}

\section{Results}

\section{The statistical model used:}

This research depended in analyzing its results on a heptachlor model for analyzing educational research 
data (Al-Said, 2001 : 573-614) as it leads to achieving the necessary conditions needed for performing a good statistical analysis and interpreting the results of this analysis. Each hypothesis had been tested by following the seven stages of the model which were as follows; the preliminary analysis, the exploratory analysis, the performativity analysis, the affirmative analysis, the iterative analysis, the frequency analysis and the integrative analysis. SPSS (Statistical Package for the Social Sciences, version16) was used to analyze students' scores on the pre and post-tests. Results are shown in the light of the study hypotheses and questions.

\section{Hypothesis One:}

"There is a statistically significant difference between the post-test administration mean scores of the experimental and the control groups in critical writing skills test in favor of the experimental group".

In order to validate this hypothesis, data had been described and summarized through calculating the mean, the standard deviation of the two groups; the experimental group and the control group as shown in table ( 2 ).

Table ( 2 ) shows that the value of the mean score of the experimental group was (42.3) which is higher than that of the control group which was (16.3). As table (2) shows, there existed a raise in the scores of the experimental group than those of the control group in the post administrations of Critical writing skills test. It also shows the increasing homogeneity of grades of the experimental group than the control group due to 
teaching the experimental group through diaries learning.

Table ( 2 ): Descriptive Statistics to the Scores of Students of the Control Group and the Experimental Group in Critical writing skills.

\begin{tabular}{|c|c|c|c|c|c|}
\hline skills & Group & $\mathbf{N}$ & Mean & $\begin{array}{l}\text { Std. } \\
\text { Deviation }\end{array}$ & $\begin{array}{l}\text { total } \\
\text { score }\end{array}$ \\
\hline \multirow{2}{*}{$\begin{array}{l}\text { Uses paragraphs to develop and } \\
\text { expand ideas }\end{array}$} & Experimental & 30 & 8.5 & 0.68 & \multirow[t]{2}{*}{9} \\
\hline & Control & 30 & 3.2 & 0.92 & \\
\hline \multirow{2}{*}{$\begin{array}{l}\text { Give a clear and precise account of } \\
\text { the relevant evidence and arguments }\end{array}$} & Experimental & 30 & 8.5 & 0.68 & \multirow[t]{2}{*}{9} \\
\hline & Control & 30 & 2.93 & 1.20 & \\
\hline \multirow[t]{2}{*}{ Give reasons for conclusion } & Experimental & 30 & 8.43 & 0.77 & \multirow[t]{2}{*}{9} \\
\hline & Control & 30 & 3.47 & 0.57 & \\
\hline \multirow{2}{*}{$\begin{array}{c}\text { Recognizes limitations (tends, } \\
\text { suggests) }\end{array}$} & Experimental & 30 & 8.63 & 0.55 & \multirow[t]{2}{*}{9} \\
\hline & Control & 30 & 3.53 & 1.10 & \\
\hline \multirow[t]{2}{*}{ Avoid simplistic conclusions } & Experimental & 30 & 8.23 & 0.81 & \multirow[t]{2}{*}{9} \\
\hline & Control & 30 & 3.17 & 1.05 & \\
\hline \multirow[t]{2}{*}{ Critical writing skills } & Experimental & 30 & 42.3 & 1.46 & \multirow[t]{2}{*}{9} \\
\hline & Control & 30 & 16.3 & 1.84 & \\
\hline
\end{tabular}

This is represented graphically in figure ( 1 )

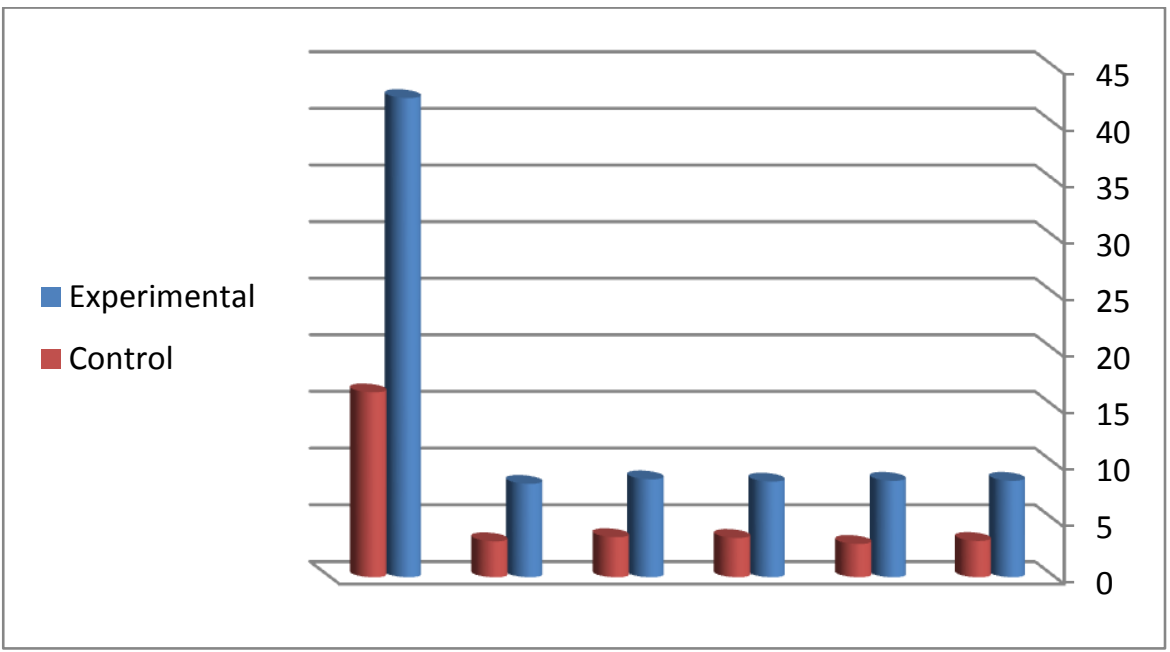

Figure ( 1 ) Bar Charts of the Mean Scores of the Control Group and the Experimental Group in the Post Critical writing test administration. 
To study the significance of the differences, t-value was calculated for the difference between the mean scores of the two groups; as illustrated in table (3 ):

Table ( 3 ): The t-value to Signify the Difference between the Mean Scores of the Two Groups in the Post administration.

\begin{tabular}{|c|c|c|c|c|c|c|c|c|c|c|}
\hline Skills & Group & $\mathbf{N}$ & Mean & $\begin{array}{c}\text { Std. } \\
\text { Deviation }\end{array}$ & $\begin{array}{c}\text { t- } \\
\text { value }\end{array}$ & $\begin{array}{l}\text { d. } \\
\text { f }\end{array}$ & sig & ${ }^{2} \eta$ & $\begin{array}{l}\text { Effect } \\
\text { size d }\end{array}$ & $\begin{array}{c}\text { Practical } \\
\text { significance }\end{array}$ \\
\hline $\begin{array}{c}\text { Uses } \\
\text { paragraphs }\end{array}$ & $\begin{array}{c}\text { Experime } \\
\text { ntal }\end{array}$ & 30 & 8.5 & 0.68 & \multirow{2}{*}{$\begin{array}{c}25.26 \\
0\end{array}$} & \multirow[t]{2}{*}{58} & \multirow{2}{*}{$\begin{array}{c}\text { Signifi } \\
\text { cant } \\
\text { at } \\
(0.01)\end{array}$} & \multirow[b]{2}{*}{0.91} & \multirow[b]{2}{*}{3.17} & \multirow{2}{*}{$\begin{array}{c}\text { Significant } \\
\qquad \& \\
\text { educationall } \\
\text { y important }\end{array}$} \\
\hline $\begin{array}{c}\text { to develop } \\
\text { and expand } \\
\text { ideas }\end{array}$ & Control & 30 & 3.2 & 0.92 & & & & & & \\
\hline \multirow{2}{*}{$\begin{array}{l}\text { Give a clear } \\
\text { and precise } \\
\text { account of } \\
\text { the relevant } \\
\text { evidence and } \\
\text { arguments }\end{array}$} & $\begin{array}{c}\text { Experime } \\
\text { ntal }\end{array}$ & 30 & 8.5 & 0.68 & \multirow{2}{*}{$\begin{array}{c}22.06 \\
6\end{array}$} & \multirow[t]{2}{*}{58} & \multirow{2}{*}{$\begin{array}{c}\text { Signifi } \\
\text { cant } \\
\text { at } \\
(0.01)\end{array}$} & \multirow[b]{2}{*}{0.89} & & \multirow{2}{*}{$\begin{array}{c}\text { Significant } \\
\qquad \& \\
\text { educationall } \\
\text { y important }\end{array}$} \\
\hline & Control & 30 & 2.93 & 1.20 & & & & & 2.84 & \\
\hline \multirow{2}{*}{$\begin{array}{c}\text { Give } \\
\text { reasons for } \\
\text { conclusion }\end{array}$} & $\begin{array}{c}\text { Experime } \\
\text { ntal }\end{array}$ & 30 & 8.43 & 0.77 & \multirow{2}{*}{$\begin{array}{c}28.28 \\
1\end{array}$} & \multirow[t]{2}{*}{58} & \multirow{2}{*}{$\begin{array}{l}\text { Signifi } \\
\text { cant } \\
\text { at } \\
(0.01)\end{array}$} & \multirow[b]{2}{*}{0.93} & & \multirow{2}{*}{$\begin{array}{c}\text { Significant } \\
\qquad \& \\
\text { educationall } \\
\text { y important }\end{array}$} \\
\hline & Control & 30 & 3.47 & 0.57 & & & & & 3.64 & \\
\hline \multirow{2}{*}{$\begin{array}{c}\text { Recognizes } \\
\text { limitations } \\
\text { (tends, } \\
\text { suggests) }\end{array}$} & $\begin{array}{c}\text { Experime } \\
\text { ntal }\end{array}$ & 30 & 8.63 & 0.55 & \multirow{2}{*}{$\begin{array}{c}22.56 \\
7\end{array}$} & \multirow[t]{2}{*}{58} & \multirow{2}{*}{$\begin{array}{c}\text { Signifi } \\
\text { cant } \\
\text { at } \\
(0.01)\end{array}$} & \multirow[b]{2}{*}{0.89} & & \multirow{2}{*}{$\begin{array}{c}\text { Significant } \\
\qquad \& \\
\text { educationall } \\
\text { y important }\end{array}$} \\
\hline & Control & 30 & 3.53 & 1.10 & & & & & 2.84 & \\
\hline \multirow{2}{*}{$\begin{array}{c}\text { Avoid } \\
\text { simplistic } \\
\text { conclusions }\end{array}$} & $\begin{array}{c}\text { Experime } \\
\text { ntal }\end{array}$ & 30 & 8.23 & 0.81 & \multirow{2}{*}{$\begin{array}{c}20.81 \\
8\end{array}$} & \multirow[t]{2}{*}{58} & \multirow{2}{*}{$\begin{array}{l}\text { Signifi } \\
\text { cant } \\
\text { at } \\
(0.01)\end{array}$} & \multirow[b]{2}{*}{0.88} & & \multirow{2}{*}{$\begin{array}{c}\text { Significant } \\
\qquad \& \\
\text { educationall } \\
\text { y important }\end{array}$} \\
\hline & Control & 30 & 3.17 & 1.05 & & & & & 2.7 & \\
\hline \multirow[t]{3}{*}{$\begin{array}{c}\text { Critical } \\
\text { writing skills }\end{array}$} & $\begin{array}{c}\text { Experime } \\
\text { ntal }\end{array}$ & 30 & 42.3 & 1.46 & \multirow{3}{*}{$\begin{array}{c}60.51 \\
5\end{array}$} & \multirow[t]{3}{*}{58} & \multirow{3}{*}{$\begin{array}{c}\text { Signifi } \\
\text { cant } \\
\text { at } \\
(0.01)\end{array}$} & \multirow{3}{*}{0.98} & & \multirow{3}{*}{$\begin{array}{c}\text { Significant } \\
\qquad \& \\
\text { educationall } \\
\text { y important }\end{array}$} \\
\hline & Control & 30 & 16.3 & 1.84 & & & & & & \\
\hline & & & & & & & & & 7 & \\
\hline
\end{tabular}

It is clear from table ( 3 ) that the calculated value of " $\mathrm{t}$ " (60.515) is higher than the tabulated value of " $\mathrm{t}$ " at 58 degrees of freedom and significant level "0.01" ; which meant that the difference between the mean 
scores of the two groups reached the level of statistical significance. In order to investigate the effect and educational importance of the results and its educational importance and effectiveness; the value of ETA square $\left({ }^{2} \eta\right)$ and the effect size (d) were calculated as its value (ETA square) was 0.98 . ETA square value which was significant to the height effect and educational importance and the practical significance exceeded the results in the psychological researches which were 0.14 . And in the light of this, It can be said that $98 \%$ of the variations between the scores of students in the critical writing skills could be due to differences of teaching treatment which the two groups were exposed to, and that there was height effect and educational importance for using diary for improving and developing critical writing skills.

Thus, the hypothesis was accepted which indicated that "There is a statistically significant difference between the post-test administration mean scores of the experimental and the control groups in critical writing skills in favor of the experimental group."

\section{Hypothesis Two:}

"There is a statistically-significant difference between the mean scores of the experimental group students on the pre and post administrations of the critical writing skills test in favor of the post administration."

In order to validate this hypothesis, data had been described and summarized through calculating the mean, the standard deviation of the pre-post administrations. of the experimental group, as shown in table ( 4 ). 
Table ( 4 ): Descriptive Statistics to the Scores of Students of the prepost administrations. of the Experimental Group in Critical writing skills.

\begin{tabular}{|c|c|c|c|c|c|}
\hline skills & Group & $\mathbf{N}$ & Mean & Std. Deviation & total score \\
\hline \multirow{2}{*}{$\begin{array}{l}\text { Uses paragraphs to develop and } \\
\text { expand ideas }\end{array}$} & Pre & 30 & 2.0333 & .88992 & \\
\hline & Post & 30 & 8.5000 & .68229 & \\
\hline \multirow{2}{*}{$\begin{array}{l}\text { Gives a clear and precise account of } \\
\text { the relevant evidence and arguments }\end{array}$} & Pre & 30 & 2.6000 & .89443 & \\
\hline & Post & 30 & 8.5000 & .68229 & \\
\hline \multirow[t]{2}{*}{ Gives reasons for conclusion } & Pre & 30 & 2.1667 & .79148 & \\
\hline & Post & 30 & 8.4333 & .77385 & \\
\hline \multirow{2}{*}{$\begin{array}{c}\text { Recognizes limitations (tends, } \\
\text { suggests..) }\end{array}$} & Pre & 30 & 2.0000 & .87099 & \\
\hline & Post & 30 & 8.6333 & .55605 & \\
\hline \multirow[t]{2}{*}{ Avoid simplistic conclusions } & Pre & 30 & 1.6667 & .92227 & \\
\hline & Post & 30 & 8.2333 & .81720 & \\
\hline \multirow[t]{2}{*}{ Critical reading skills } & Pre & 30 & 10.4667 & 1.94286 & \\
\hline & Post & 30 & 42.3000 & 1.46570 & \\
\hline
\end{tabular}

Table ( 4 ) shows that the value of the mean score of the post adm. was (42.3) which is higher than that of the pre adm. which was (10.4). As table ( ) shows, there existed a raise in the scores of the post administration than those of the pre administration in the critical reading skills test. It also shows the increasing homogeneity of grades of the experimental group in the post administration due to teaching the experimental group through 4/ MAT and allowing for multiple right answers strategies.

This is represented graphically in figure (2 )

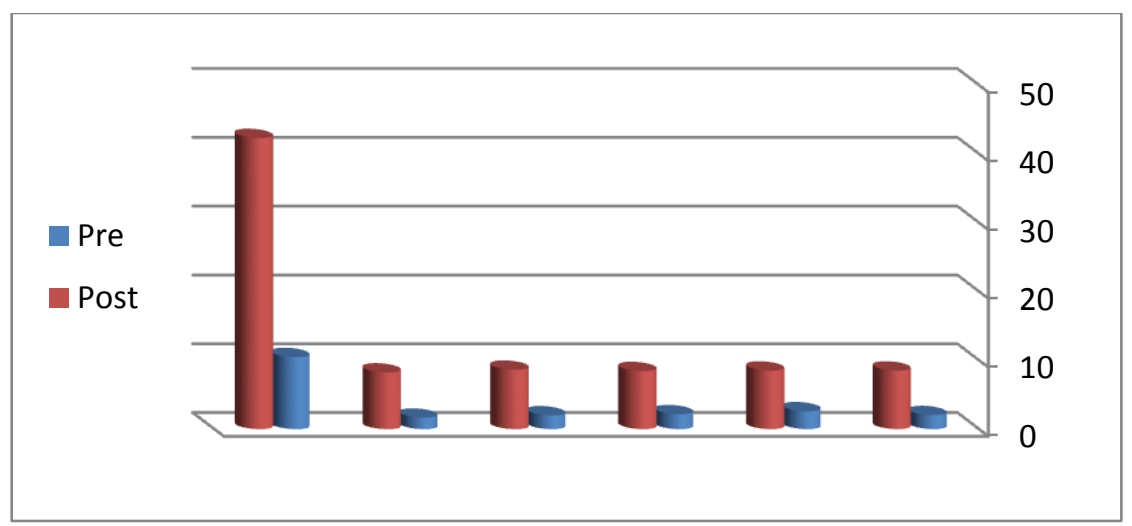

Figure ( 2 ) Bar Charts of the Mean Scores of the pre-post administrations of the Experimental Group in Critical writing skills. 


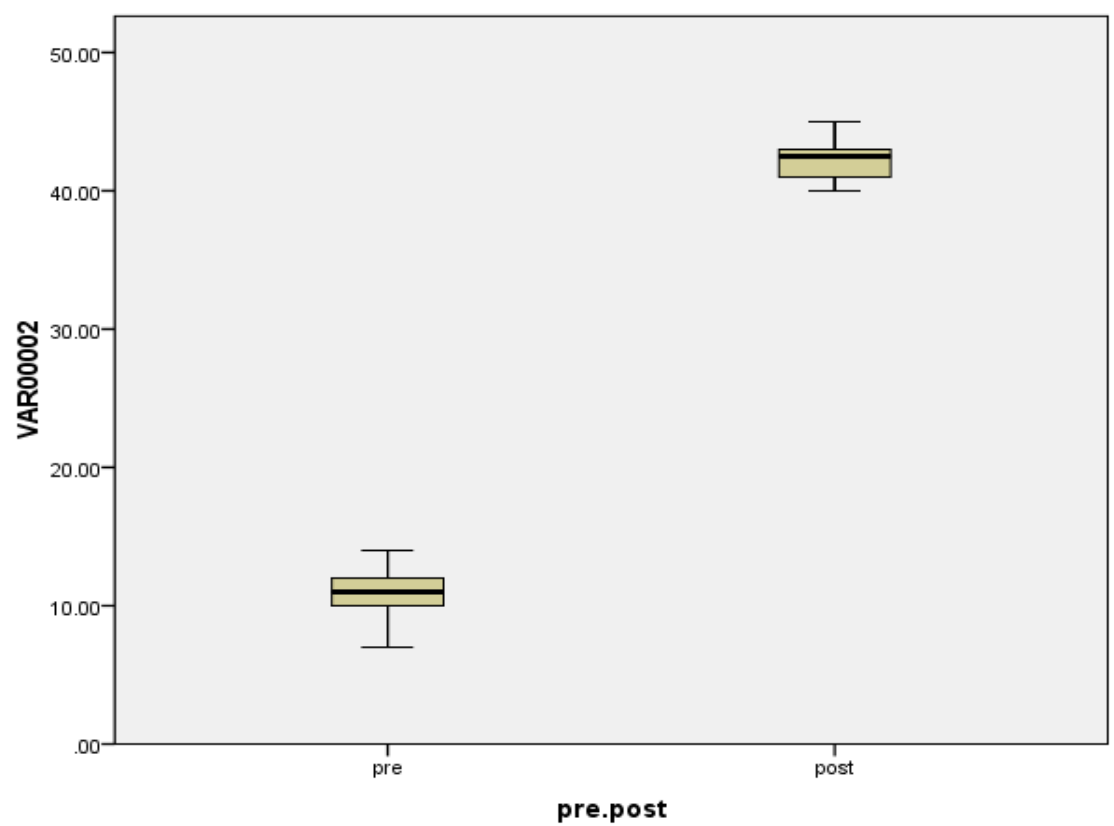

Figure ( 3 ) Box Plot Chart of Scores of pre-post administrations of the Experimental Group in Critical writing skills

\begin{tabular}{|c|c|c|c|}
\hline \multicolumn{4}{|c|}{ Statistics } \\
\hline & & $\begin{array}{c}\text { criticallistenings } \\
\text { killspre }\end{array}$ & $\begin{array}{c}\text { criticallistenings } \\
\text { killspost }\end{array}$ \\
\hline \multirow[t]{2}{*}{$\mathbf{N}$} & Valid & 30 & 30 \\
\hline & Missing & 0 & 0 \\
\hline \multicolumn{2}{|c|}{ Minimum } & 7.00 & 40.00 \\
\hline \multicolumn{2}{|c|}{ Maximum } & 14.00 & 45.00 \\
\hline \multirow[t]{3}{*}{ Percentiles } & 25 & 9.7500 & 41.0000 \\
\hline & 50 & 11.0000 & 42.5000 \\
\hline & 75 & 12.0000 & 43.2500 \\
\hline
\end{tabular}

Its appears from charts that there is a variance between the two administrations. and the previous chart can be summarized in the following table (5) 


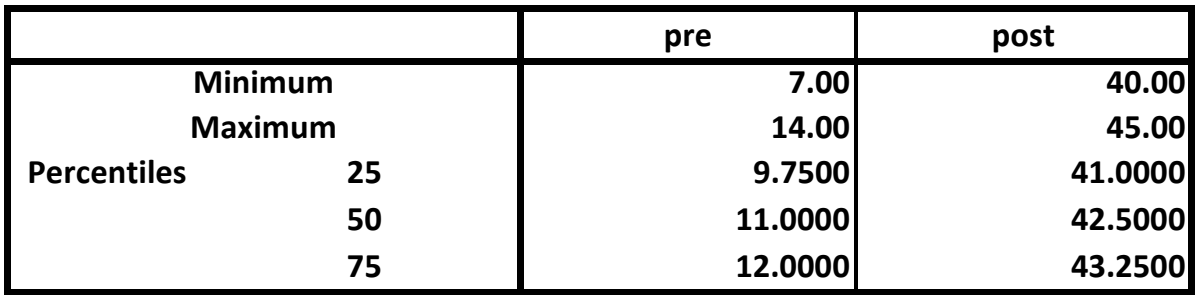

To study the significance of the differences, $t$-value (Paired samples $t$ - test) was calculated for the difference between the mean scores of the two administrations as illustrated in table (5):

Table (6): The t-value to Signify the Difference between the Mean Scores of the two administrations.

\begin{tabular}{|c|c|c|c|c|c|c|c|c|c|}
\hline Skills & $\mathbf{N}$ & $\begin{array}{c}\text { Difference } \\
\text { Mean }\end{array}$ & $\begin{array}{c}\text { Std. } \\
\text { Deviation }\end{array}$ & t-value & d.f & sig & ${ }^{2} \eta$ & $\begin{array}{c}\text { Effect } \\
\text { size } \\
\text { d }\end{array}$ & $\begin{array}{c}\text { Practical } \\
\text { significance }\end{array}$ \\
\hline 1 & 30 & 6.46 & .93710 & 37.79 & 29 & $\begin{array}{l}\text { Significant } \\
\text { at }(0.01)\end{array}$ & 0.98 & 7.01 & $\begin{array}{l}\text { Educationall } \\
\text { y important }\end{array}$ \\
\hline 2 & 30 & 5.9 & .88474 & 36.52 & 29 & $\begin{array}{c}\text { Significant } \\
\text { at }(0.01)\end{array}$ & 0.97 & 6.78 & $\begin{array}{l}\text { Educationall } \\
\text { y important }\end{array}$ \\
\hline 3 & 30 & 6.26 & .73968 & 46.4 & 29 & $\begin{array}{l}\text { Significant } \\
\text { at (0.01) }\end{array}$ & 0.98 & 8.61 & $\begin{array}{l}\text { Educationall } \\
\text { y important }\end{array}$ \\
\hline 4 & 30 & 6.63 & 1.15917 & 31.34 & 29 & $\begin{array}{l}\text { Significant } \\
\text { at }(0.01)\end{array}$ & 0.97 & 5.81 & $\begin{array}{l}\text { Educationall } \\
\text { y important }\end{array}$ \\
\hline 5 & 30 & 6.56 & .77385 & 46.47 & 29 & $\begin{array}{l}\text { Significant } \\
\text { at }(0.01)\end{array}$ & 0.98 & 8.62 & $\begin{array}{l}\text { Educationall } \\
\text { y important }\end{array}$ \\
\hline $\begin{array}{l}\text { Critica } \\
\text { I } \\
\text { readin } \\
\text { g } \\
\text { skills }\end{array}$ & 30 & 31.83 & 2.18274 & 79.88 & 29 & $\begin{array}{c}\text { Significant } \\
\text { at }(0.01)\end{array}$ & 0.99 & 14.83 & $\begin{array}{l}\text { Educationall } \\
\text { y important }\end{array}$ \\
\hline
\end{tabular}

It is clear from table (6) that the calculated value of " $t$ " (79.88) is higher than the tabulated value of " $t$ " at 29 degrees of freedom and significant level "0.01" ; which meant that the difference between the mean scores of the two administrations. reached the level of statistical significance. In order to investigate the effect 
and educational importance of the results and its educational importance and effectiveness; the value of ETA square $\left({ }^{2} \eta\right)$ and the effect size (d) were calculated as its value (ETA square) was 0.99. ETA square value which was significant to the height effect and educational importance and the practical significance exceeded the results in the psychological researches which were 0.14 . And in the light of this, It can be said that $99 \%$ of the variations between the scores of students in the critical writing skills could be due to the teaching treatment, and that there was height effect and educational importance for using diaries learning for improving and developing critical writing skills.

Thus, the hypothesis was accepted which indicated that "There is a statistically-significant difference between the mean scores of the experimental group students on the pre and post administrations of the critical writing skills test in favor of the post administration.

\section{Discussion:}

The statistical analysis presented in this study resulted in answering the study questions and verifying its hypothesis. The study was conducted to develop critical writing. The study also aimed at investigating the effect of diaries learning on language skills in critical writing for first year of department of English.

To achieve the aims of the study a critical writing test was administered to 60 pupils in Al Azhar preparatory school. There are many findings obtained by the developed test that warrant further discussion. 
The statistical analysis of students' total mean scores on each reading component indicated that the experimental group demonstrated best performance levels on the critical writing components.

\section{The results of the test are presented according to these themes:}

From the findings above we could conclude that learners (Al Azhar preparatory school pupils) are not analytical or critical when they write and tend to use surface level processing in writing all which suggest they are not ready to write critical sentences. They tend to simple sentences and they could not understand the rules of critical writing. They also cannot follow the steps of writing or write lines that have deeper meaning. This may indicate that the teachers in schools have not really prepared them to be critical writers or in other words they are lacking in critical writing skills. If they possess critical writing skills they would definitely be able to analyze, synthesize, and evaluate what they write, and try to use critical thinking skills for example, to accept or reject the ideas in the text. Therefore, it is imperative for critical writing skills be taught to students in schools to prepare them for tertiary education.One important thing that teachers tend not to stress when teaching writing to students and this may lead to not teaching the critical writing skills is when they do not teach students to construct meaning from the text during the writing process. Wallace (2003) has used the word, discourse" to describe the meaning that we get from a text . 
The following suggestions might be given based on the findings of the study:

1. Functional courses to improve students' critical writing knowledge and skills might be included in the undergraduate programs.

2. Critical writing courses should be a part of curriculum from the beginning of primary education to higher education programs.

3. This study attempts to explore the views of primary school teacher candidates about critical writing and their perceptions of competence. Similar studies might be conducted with other primary school teacher candidates at other universities.

4. The findings of the study are limited to the data collected via semi-structures interviews. Similar studies might be conducted employing quantitative research techniques with larger samples.

5. This study is limited to the views of Primary School. In the future studies, a comparative analysis might be done by including different samples to the study

The results of this research confirmed the effectiveness of employing the Diaries Learning to teach developmental English critical writing skills. Results are also were consistent with other studies conducted in EFL classrooms. Nachaivieng studied achievement in English using the Learning Diaries with secondary level students. It was found that student learning achievement in English were higher than the set criterion (70 percent). This study was also consistent with Kiewkun, who examined achievement in learning 
English for communication using the Diaries Learning with Grade 5 students. These results showed that the students' English learning achievement was significantly higher than before the instruction.In addition, the students' attitude towards learning English critical writing using the Diaries Learning was found to be at a good level. It might be that the steps of teaching are sequential and the students are supported by knowledge in each of the components. The students were provided with opportunity in learning essential samples of critical writing of the proposed topics. Their confidence in critical writing and sharing their experience is built by presenting their work in the classroom.

\section{Finally the research concludes these results :}

1. First : The use of Learning Diaries increases pupils' critical writing skills. This can take place through developing their abilities to learning and identifying new words, anticipate what a passage is going to be about and how it is going to finish, refer to information in the passage, and connect with previous knowledge .

2. Second: Learning Diaries helps students acquire selfmonitoring and problem solving skills through the use of student partnerships for practice with each student participating in writing and tackling passages from different perspectives .

3. Third: Learning Diaries could be used to improve and foster critical writing skills in students.

4. Fourth: Learning Diaries was an opportunity for building students' cooperation and dedication to their groups . 
5. Finally: learning Diaries could create situations for pupils to show respect for themselves, the others and the environment.

Pupils can write and think at the same time: instructors just need to guide student critical writing with purposeful strategy. Using this system allows the teacher to provide different instructional strategies for everyone when learning new information. Each type of learner is offered an opportunity to learn using this model. Furthermore, each type of learner can acquire the ability to adapt to other learning style situations so as to become a more complete and open-minded person who now possesses alternate ways of gaining new information.

\section{References}

- Alber, S. \& Heward, W. (2000) .Allison, D. (1998). Investigating learner's course diaries as explorations of language .Language Teaching Research, 2(1),24-47.

- Bagheri, S. \& Pourgharib, B. (2013). An investigation of the effect of journal writing on EFL learners' oral production. International Research Journal of Applied and Basic Sciences, 4 (11), 3520-3525 .

- Bailey, K. (1990). The use of diary studies in teacher education programs. In J. C .

- Richards \& D. Nunan (Eds.). Second language teacher education. (pp. 215-226) Cambridge: Cambridge University Press.

- Bailey, K.; \& Nunan, D. (Eds) (1996). Voices from the language classroom: Qualitative Research in second language classroom. Cambridge University Press ‘Cambridge .

- Barjesteh, H.; Vaseghi, R. \& Gholami, R. (2011). The effect of diary writing on EFL college students' writing improvement and attitudes. International Conference on Languages, Literature and Linguistics IPEDR, 26, 143-147 . 
- Baumeister, R.; Hutton, D. \& Gairns, K. (1990). Negative effect of praise on skilled performance. Basic and Applied Social Psychology, 11,131-148.

- Bitchener, J. (2008). Evidence in support of written corrective feedback. Journal of Second Language Writing, 17,102-118 .

- Bluestein, J. (2004). Practical strategies for working successfully with difficult students .Bellevue, WA: Bureau of Education and Research .

- Corpus, J.; Ogle, C. \& Love-Geigner, K. (2006). The effects of social-comparison versus mastery praise on children's intrinsic motivation. Motivation and Emotion, 30,335-345.

- Curtis, A., \& Bailey, K. (2009). Diary studies: Research Digest. OnCUE Journal 85-57, (1)3.

- Daiker, D. (2011). Learning to praise. In I. L. Clark concepts in composition: Theory and practice in the teaching of writing (2nd Ed.). New York: Routledge .

- Ferris, D. (2002). Treatment of error in second language writing classes. Ann Arbor, MI : University of Michigan Press.

- Ferris, D. (2004). The "grammar correction" debate in L2 writing: Where are we, and where do we go from here? (and what do we do in the meantime...?) Journal of Second Language Writing, 13,49-62 .

- Fitriana, D. (2009). The students' ability in creating written recount texts. PhD Thesis . University of Negeri Semarang. Indonesia .

- Goldstein, L. (2004). Questions and answers about teacher written commentary and student revision: Teachers and students working together. Journal of Seocnd Language Writing, 13,63-80.

- Guy, L. (2004). Diaries and Journals: an aid to learning? Report on the findings of a research project funded by the General Teaching for Scotland (April 2004.(

- Haimovitz, K.; Corpus, J. (2011). Effects of a person versus process praise on student motivation: Stability and change in emerging adulthood. Educational Psychology: An 
international journal of experimental educational psychology, 1-15 I First Article.

- Hamp-Lyons, L. \& Heasly, B. (2006). Study writing (2nd Ed.). Cambridge: Cambridge University Press .

- Harmer, J. (2004). How to teach writing. Essex: Longman Group Ltd .

- Hidayat, T. (2011). The use of diary writing method to improve students' writing recount British Journal of Education

- Kirkgoz, Y.(2009). Exploring growth in vocabulary learning through learner diaries .Proceedings of the 10th METU ELT Convention .

- Lewis, K. (2009). Adult learners' perceptions of the incorporation of their L1 in foreign language teaching and learning. Applied Linguistics, 30(2),216-235.

- Lipnevich, A. \& Smith, J. (2008). Response to assessment feedback: The effects of grades, praise, and source of information. Educational Testing Service http://www.ets.org/reserch/content.html.

- Ningrum, V., Rita, F. \& Hastini (2013). E-Journal of English Language Teaching Society (ELTS), 1 (1),1-13.

- Patterson, D. (2014). Using writing journals as a means of increasing EFL writing fluency. Proceedings of ICLC 2013: The 5th International Conference on Language \& Communication, 81-91.

- Peterson, J. (2012). A self-directed approach to Turkish language acquisition: Diary study. MA Thesis. Hamline University, Saint Paul, Minnesota .

- Safitri, Y. (2011). The effect of using diary on the eight grade students' achievement in writing a recount text at SMPN 2 BANGIL. PHD Thesis. Jember University .

- Schunk, D. \& Zimmerman, B. (2012). Motivation \& selfregulated learning: Theory Research and applications. New York: Taylor \& Francis Group . 
- Shaughnessy, M. (1977). Errors and expectations: A guide for the teacher of basic writing. New York: Oxford UP.

- Straub, R. (1997). Students' reactions to teacher comments: an exploratory study .Research in the Teaching of English, 31(1),91-119 .

- Truscott, J. (2004). Evidence and conjecture on the effect of correction: A response to Chandler. Journal of second Language Writing, 13,337-343.

- Truscott, J. (2007). The effect of error correction on learners' ability to write accurately .Journal of Second Language Writing, 16,255-272.

- Truscott, J. \& Hsu, A. (2008). Error correction, revision and learning. Journal of Seocnd Language Writing, 17,292-305.

- Tuan, L. (2010). Enhancing EFL learners' writing skill via journal writing. English Language Teaching, 3(3), 81-88.

- Temple, C. (2013). Preparing students for active involvement in community life. In the New Academic Paradigm: Centering on the Client, Ed. Cluj University Press, Cluj-Napoca, pp. 87-94.

- Walter, E. (2008). Journaling as writing, reflection, and personal expression .CamTESOL Conference on English Language Teaching: Selected Papers, 4,120-131 .

- Zittoun, T.; Gillespie, A. (2011). In E. Abbey \& S. Surgan, (eds). Using diaries and selfwritings as data in Psychological research. Emerging Methods in Psychology: History \& theory of Psychology. Transaction Publishers, New Brunswick, New Jersey, USA.

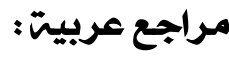

- السعيد ، رضا مسعد (ب..r) : نموذج منظومي لتظوير مهارات التفكير الإحصائي لدى الباحثين

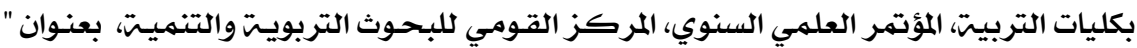

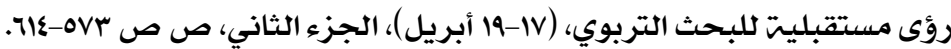

